\title{
Knitted Bandages for Animal Care and their Production Technology
}

\author{
Alexander Oks ${ }^{1}$, Ilze Bernikova ${ }^{2}$, Jelena Oksa ${ }^{3}$, Agris Ilgažs ${ }^{4},{ }^{1-2}$ Riga Technical University, Institute of Textile \\ Materials Technologies and Design, ${ }^{3}$ Kengaraga veterinary ambulance, ${ }^{4}$ Latvia University of Agriculture, \\ Veterinary Clinic
}

\begin{abstract}
A new type of knitted bandages for wound cover for animals is proposed. Properties of different knitted stitches are compared and tested to provide good elasticity and breathability of bandage and the possibility to cut any necessary length and openings in it. The Technology of the production of the proposed bandages is developed.
\end{abstract}

Keywords: Bandage, knitting, technology, veterinary.

\section{INTRODUCTION}

It has long been recognized that wounds should be protected while healing. For example, a bandage is applied to a laceration to physically support the skin at the laceration and to reduce the chance of infection. The term "wound" is broadly defined herein to describe any internal (e.g., broken bone) or external (e.g., laceration) injury caused by sickness or intentional (e.g., surgery) or unintentional trauma.

Conventional wound covers for animals are simply adaptations of wound covers for humans. Sterile gauze bandages, white plaster casts, and stitches developed for humans are all applied to animals. But the covering of a wound presents unique problems when the wound is on an animal. Initially, the animal cannot be expected to cooperate in the healing process. On the contrary, an animal may have natural instincts that cause it to act in a manner that is detrimental to it. For example, an animal may lick, bite, or scratch a wound following surgery; this licking may harm surgical stitches and increases the likelihood of infection. An animal may also scratch at a bandage that causes discomfort.

Conventional wound covers not only present physical problems when applied to animals, but they can also cause psychological problems that are more intense in animals. A conventional wound cover may make the animal which the wound cover is applied to feel isolated and vulnerable, especially when it is with other animals. And other animals will often act aggressively towards the animal wearing a wound cover because the wounded animal looks different. [1].

Most of modern special devices which inhibit the animal's ability to bite or lick its wound can be represented as different versions of collars. Unfortunately such devices can interfere with the animal's vision, eating, drinking, self-grooming, and play. A Rather effective and popular is"an apron". But it also disturbs animals and restricts their free movement. There are some versions of special protective garments [1]. But in this case a lot of sizes are necessary and the product is rather complicated and comparatively expensive. Unfortunately, all such garments and devices don't give a possibility to cover the neck zone of an animal, too. So, the development of effective wound covers for animals is still an topical and a rather complicated problem.

\section{ANALYSIS OF BANDAGE PROPERTIES}

In order to create and to offer a new type of wound cover for the use in veterinary medicine, the demands for such covers were specified by a survey among veterinarian specialists in Latvia. The results of the survey are shown in Fig.1.

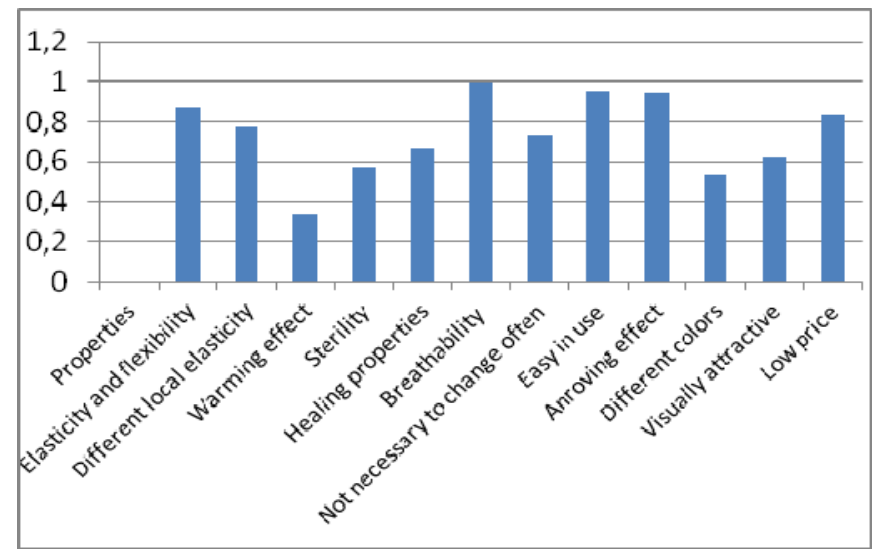

Fig.1 The results of survey

It can be seen from Fig. 1 what are the main demands and expected properties of wound covers are:

- breathability

- ease of use

- low unroving effect

- elasticity and flexibility

- low cost

To satisfy these demands an "endless" elastic knitted tubular band (bandage of 5-10 meters length) with specific technological properties was proposed for wound covering. [2]. Its properties are: knitting stitches have to be of a ladder proof structure, should have untwisted property for bandage edges, a very high elasticity and extensibility, low density and weight. Such properties guarantee breathability of a bandage, a possibility to cut a wound cover of any necessary length and any necessary openings without their fixing, which makes the proposed bandages easy, convenient and economical in use. To provide an elasticity of wound cover and, therefore, a good fit to animal's body, and also taking into consideration 
ecological aspect to produce bandages from natural yarns in bland with polyurethane (elasthane or lycra) and polyester (PE) or polyamide (PA), the use of elastic threads was proposed.

The analysis of properties of well-known knitting stiches [3] showed that most of the above-mentioned demands can be satisfied by application the following knitted stitches:

- Rib $1+1$

- Cardigan stitch

- Half-cardigan stitch

- Interlock

Rib 1+1 stitch does not have a ladder resist structure. But has other necessary technological properties. So, potentially, it can be used as a wound cover if not necessary to cut any openings in it, then, for example, as a wound protector in a neck zone.

Cardigan and interlock stitches completely satisfy the requirements from the point of view of elasticity, effects of low unroving and highelastic recovery effects. But to produce small diameter tubular knitted bands without sewing operation using such stitches, special small diameter secular machines are necessary. Such type of equipment is not available in Latvia at the moment.

Taking into consideration present technological possibilities of knitting equipment of Latvian enterprises rib $1+1$ and halfcardigan stitches were chosen for further analysis. Proposed bandages with such stitches can be produced using double cylinder hosiery machines with lower take-off mechanism. These machines also provide a possibility to produce plating knitting which would improve elastic properties and appearance of the product.

\section{THE RESULTS OF SAMPLE TESTING}

To develop a technology of bandage manufacturing and to control their properties, samples of bandages with different combinations of yarn feeding were knitted and tested. Double cylinder hosiery machine (cylinder diameter3 1/2”, 154 needles) was used and samples with the following feeding combinations were knitted

$\# 1$ - cotton yarn 25 tex + elasthan 2,2 tex/PE 8,4 tex;

\#2 - cotton yarn 25 tex + 2(elasthan 2,2 tex/PE 8,4 tex);

\#3 - cotton yarn 25 tex + lycra 2,2 tex/PA 7 tex;

\#4 - cotton yarn 29 tex + elasthan 2,2 tex/PE 8,4 tex;

\#5 - cotton yarn 29 tex + lycra 2,2 tex/PA 7 tex.

Such properties, as elasticity, residual deformation, breathability, yarn consumption were tested and compared. The influence of thermal stabilization on bandage properties was studied as well.

Breathability. Breathability control was made according to LVS EN ISO 9237-2001. The main results are represented in Table 1.

It can be seen from Table 1 that samples \#1 and \#3 for both half-cardigan and rib1+1 stitches have the highest breathability. Thermal stabilization of the samples leads to their breathability reduction about $25-30 \%$.
TABLE 1

BREATHABILITY COEFFICIENTS

\begin{tabular}{|c|c|c|c|}
\hline Samp.\# & $\begin{array}{c}\text { Breathability } \\
\text { coeff. before } \\
\text { thermal } \\
\text { stabilization, mm/s }\end{array}$ & $\begin{array}{c}\text { Breathability } \\
\text { coeff. after } \\
\text { thermal } \\
\text { stabilization, } \\
\text { mm/s }\end{array}$ & $\begin{array}{c}\text { Difference, } \\
\text { \% }\end{array}$ \\
\hline \multicolumn{4}{|c|}{ Half-cardigan stich } \\
\hline 1 & 469 & 341 & 27 \\
\hline 2 & 369 & 249 & 33 \\
\hline 3 & 451 & 301 & 33 \\
\hline 4 & 446 & 297 & 33 \\
\hline 5 & 438 & 299 & 32 \\
\hline & & Rib 1+1 stitch & 21 \\
\hline 1 & 414 & 326 & 30 \\
\hline 2 & 296 & 207 & 25 \\
\hline 3 & 384 & 289 & 33 \\
\hline 4 & 347 & 234 & 24 \\
\hline 5 & 321 & 245 & \\
\hline
\end{tabular}

Elasticity and residual deformation. Maximal deformations under different loading and residual deformations after unloading during specific periods of time were controlled for the tested samples.

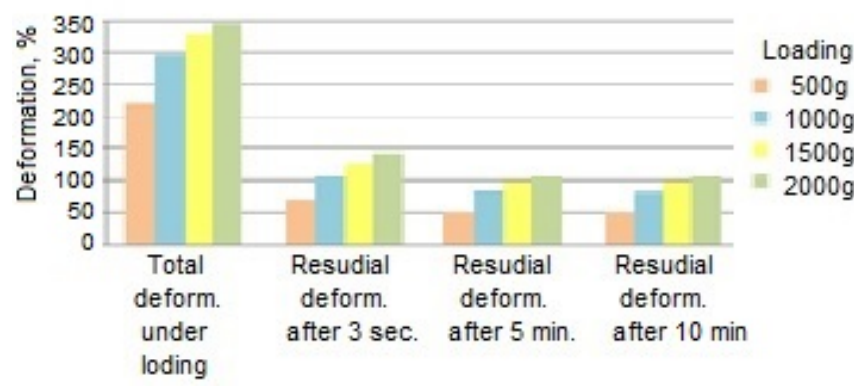

Fig.2 Deformation before thermal stabilization

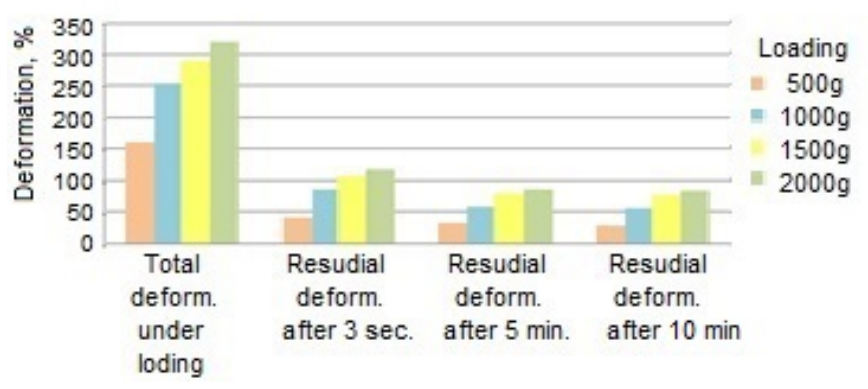

Fig.3 Deformation after thermal stabilization

As an example, Figs. 2 and 3 show test results for sample $\# 1$, a half-cardigan stitch made before and after thermal stabilization of the sample, correspondently.

Analysis of experimental data showed that samples with half-cardigan stitch have less elongation and less residual deformation than corresponding samples with rib $1+1$ stitch. So bandages knitted with half-cardigan stitch are more elastic than the ones with rib1+1. Comparative analysis of tests for 
samples with and without thermal stabilization showed that thermal treatment reduces both maximal elongation and elasticity of the samples.

Yarn consumption. Tests were made for samples $1 \mathrm{~m}$ long. Tests results are represented in Table 2.

TABLE 2

YARN CONSUMPTION

\begin{tabular}{|c|c|c|c|c|c|}
\hline Samp. \# & $\begin{array}{c}\text { Cotton } \\
25 \text { tex } \\
\text { mass, g }\end{array}$ & $\begin{array}{c}\text { Cotton } \\
\text { 29tex } \\
\text { mass, g }\end{array}$ & $\begin{array}{c}\text { El.2.2tex/ } \\
\text { Pe 8.4 } \\
\text { mass, g }\end{array}$ & $\begin{array}{c}\text { Lycra } \\
2.2 \text { tex/ PA } \\
7 \text { mass, g }\end{array}$ & $\begin{array}{c}\text { Mass } \\
\text { total, g }\end{array}$ \\
\hline \multicolumn{6}{|c|}{ Half-cardigan stich } \\
\hline 1 & 29.45 & & 11.575 & & 41.025 \\
\hline 2 & 28.7 & & 22.245 & & 50.945 \\
\hline 3 & 27.4 & & & 10.53 & 37.93 \\
\hline 4 & & 35.58 & 11.345 & & 46.925 \\
\hline 5 & & 35.235 & & 9.795 & 45.03 \\
\hline \multicolumn{6}{|c|}{ Rib 1+1 stich } \\
\hline 1 & 22.35 & & 8.665 & & 31.015 \\
\hline 2 & 22.595 & & 17.485 & & 40.08 \\
\hline 3 & 21.98 & & & 8.04 & 30.02 \\
\hline 4 & & 28.325 & 8.64 & & 36.965 \\
\hline 5 & & 26.995 & & 8.205 & 35.2 \\
\hline
\end{tabular}

It can be seen from Table 2 that lower yarn consumption for both examined stitches have samples \#3 and \#1.

Final results and their estimation. Comparative analysis of all groups of tests showed that a more preferable stitch for bandage knitting is half-cardigan because of its high elongation ability, good elasticity, breathability and property of low unroving. The Preferable feeding combination is cotton yarn 25 tex + elasthan 2.2 tex/PE 8.4 tex or cotton yarn 25 tex + lycra 2.2 tex/PA 7 tex. Thermal stabilization of bandages degrades their quality. Obviously it also increases production expenses.

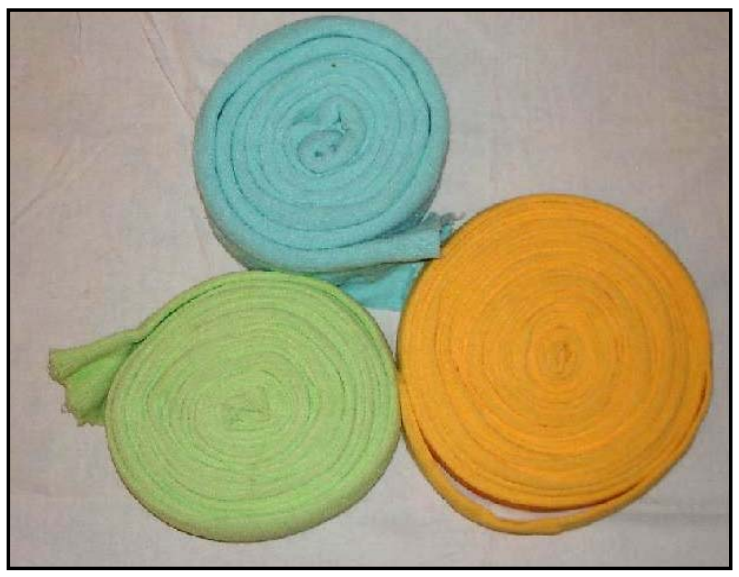

Fig.4 Tubular knitted bandages

On the basis of the present investigation sampled bandages were produced (Fig.4) and were tested for wound covering at the Faculty of Veterinarian Medicine of Latvian University of Agriculture. These tests showed that the proposed bandages are easy and convenient in use and comfortable for animals. A Bandage also gives possibility to make necessary injections directly through it without taking it off.

The Tested bandages are used in veterinarian clinics of the Baltic States now under the name DoubleAid ${ }^{T M}$ Bandages (Fig.5).

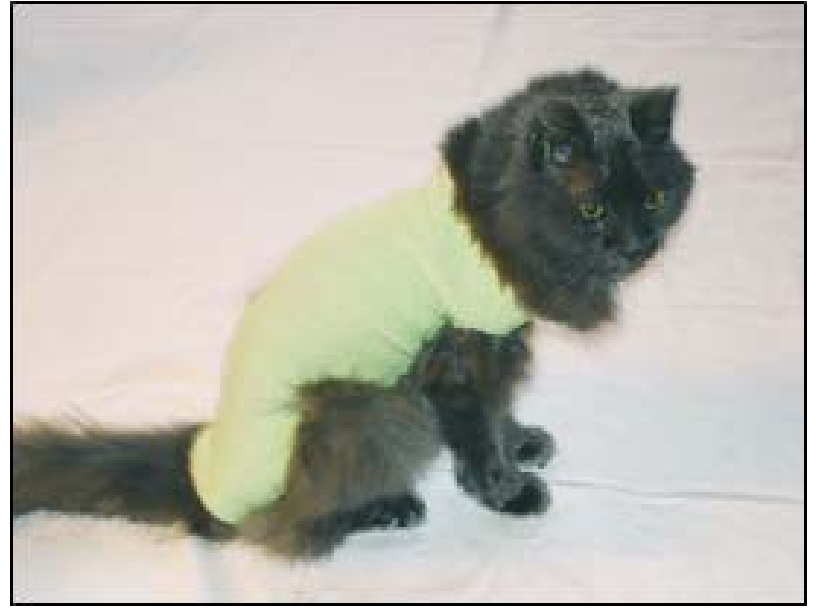

Fig.5 Application of DoubleAid ${ }^{T M}$ Bandage

\section{CONCLUSIONS}

The survey of necessary properties of wound covers for animals is made and main demands for such cover are formulated.

On the basis of formulated demands a new type of knitted bandages for wound covering for animals is proposed. Bandages are knitted as "endless" tubular bands with ladder restrict stitches which provide a possibility to cut any necessary length and openings depending on animal size and anatomical characteristics.

Breathability, elasticity, residual deformation and yarn consumption of bandages with different stitches, yarn feeding combinations and thermal treatment are compared. From medical and technological points of view most suitable variations are selected.

The technology of production of new bandages is developed. Proposed bandages are tested and applied in veterinarian clinics of Baltic States.

\section{REFERENCES}

1. Kururgija. Jāņa Gardovska red. - Rīga: Latvijas Medicīnas akadēmija/Rīgas Stradiņa universitāte: Latvijas Ķirurgu asoc., 2001. - 648 p.

2. Bette, S. Hibbert. Systems and methods for covering animal wounds. U.S. Patent 6070557 A, June 06, 2000

3. Soft E Fabric Collar [Online]. Available: http://www.amazon.com/SoftE-Fabric-Collar-Size-3/dp/B003XLBRGE/ref=sr 16 ? $=$ =petsupplies\&ie $=$ UTF $8 \&$ qid $=1370377281 \&$ sr $=1-6 \& \bar{k}$ eywords $=$ Soft$\mathrm{E}+\mathrm{Fabric}+$ Collar

4. Comfy cone [Online]. Available: http://www.allfourpaws.com/the_comfy_cone.php

5. Comfy Cone Pet E-collar [Online]. Available: http://www.amazon.com/ Comfy-Cone-E-Collar-Large-Black/dp/B000XY7CKE/ref $=$ sr 1 1 ? s=petsupplies\&ie $=$ UTF 8 \& qid $=1370377762 \&$ sr $=1-1 \&$ keywords $=$ comfy

6. Oks, B., Oks, A. Animal wound cover and the method of its production. Latvia, LV Patent 13951 B, November 20, 2009

7. Dalidovič, S. A. Osnovy teorii vjazanija Moskva: Legkaja industrija, 1970, 431p.

8. Spencer, David J. Knitting technology a comprehensive handbook and practical guide. 3rd ed. Cambridge: Woodhead Publishing, 2001. - 386 p.

9. Kolesnikova E. Vjazaljnoe oborudovanie trikotaznih fabrik. Moskva: Legprombitizdat, 1985. - 342 p.

10. LVS EN ISO 9237:2001 Tekstilizstrādājumi - Izstrādājumu gaisa caurlaidības noteikšana

11. BS 4294:1968 Methods of test for the stretch and recovery properties of fabric. 


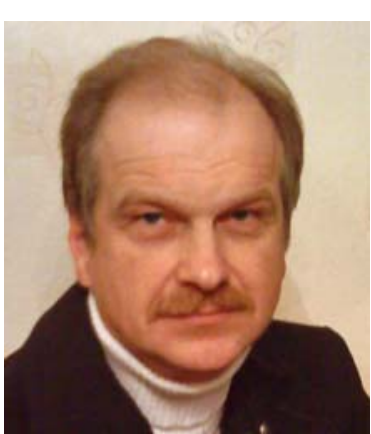

Alexader Oks graduated from Riga Polytechnical Institute in 1980 Candidate of Technical Sciences since 1985, Doctor of Technical Sciences of Russia since 1994, Dr.habil. sc. ing. since 1995. Major field is application of knitting technology in medicine and veterinary.

Researcher, Senior Researcher at Riga Technical University, Riga, Director of the manufacturing company "ESTA". Research interests include mechanical vibrations and their application in technology and diagnostics; smart textiles, application for medicine and veterinary.

Address: Riga Technical University, Institute of Textile Materials Technologies and Design, Azenes Str. 18, Riga, LV-1048, Latvia

E-mail:siiaesta@gmail.com

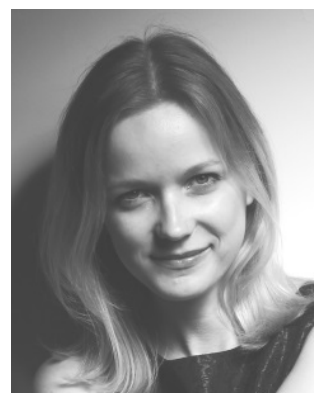

Ilze Berṇikova graduated from Riga Technical University, Faculty of Materials Science and Applied Chemistry in 2013, Bachelor of sc.ing.

Address: Riga Technical University, Institute of Textile Materials Technologies and Design, Azenes Str. 18, Riga, LV-1048, Latvia

ilze.bernikova@inbox.lv

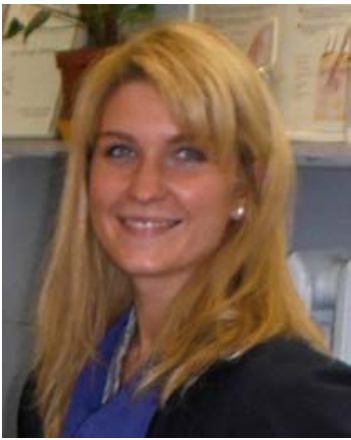

Jeḷena Oksa graduated from the Latvian University of Agriculture, Faculty of Veterinary Medicine in 2012. Master of Veterinary Medicine.

Currently she works as a Veterinary Surgeon at "Kengaraga veterinary ambulance" in Riga.

Address: Riga Kengaraga veterinary ambulance, Rencenu Str. 2, Riga, LV-

1035, Latvia

E-mail: info@kva.lv

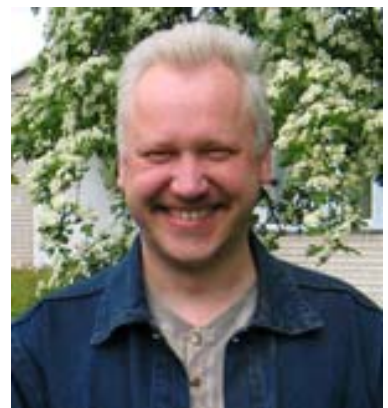

Agris Ilgažs graduated from the Latvian Academy of Agriculture in 1991. In 1998 he graduated from the Doctoral program of Veterinary Medicine. Scientific direction is associated with the Dentistry of Veterinary Medicine.

$\mathrm{He}$ is a Visiting Lecturer of LUA VMF "Clinical Institute", Veterinarian of "LUA Veterinary Clinic" and "Tornkalna veterinary clinic", Senior Menninger in the U.S. biologically active additives company "Santegra", Member of "Discoveries and Inventions of the International Academy".

Address: Veterinary Clinic of Latvia University of Agriculture, Liela Str. 2, Jelgava, LV-3001, Latvia

E-maildakteriits@inbox.lv

Aleksandrs Okss, Ilze Bernikova, Jelena Oksa, Agris Ilgažs. Dz̄ivnieku brūces aizsargājošas trikotāžas saites un to izgatavošanas tehnologiija.

Dz̄ivnieku brūču aizsargāšanai tiek lietoti adaptēti cilvēku brūču aizsargāšanai lietotie līdzekḷi, tādi kā sterili marles pārsēji, ieǵipsējumi un šuves. Dzīvnieka k̦ermeṇa īpatnības un nepakḷaušanās ārstēšanai bieži vien apgrūtina brūces džǐšanu. Piemēram, dzīvnieks var sākt laizīt, kodīt vai kasīt brūci, savukārt tas var veicināt infekcijas ieklūšanu brūcē.

Pašlaik pieejamie brūces aizsargājošie izstrādājumi dz̄inniekam var izraisīt gan fiziskas, gan emocionālas neērtības un pat traumas. Bieži vien dzīvnieki jūtas izolēti no apkārtējās pasaules, $k \bar{a}$ arī viegli ievainojami. Tāpēc atbilstošu brūčcu aizsargājošo izstrādājumu izgatavošana ir aktuāla problēma veterinārmedicīnā.

Problēmas risināšanai tiek piedāvāta jauna veida brūču pārsēju izgatavošana. Tā ir tubulārā elastīgā dažāda garuma (sākot no 5 m) un diametra trikotāžas saites. Saitei tiek izvēlēts mazirstošs pinums.

Piedāvātā brūču pārsēja priekšrocības ir tā êrtā uzlikšana un êrtums (saites ir ḷoti mīkstas, elastīgas, netraucē kustības, nodrošina labu gaisa un siltuma apmainu starp dzīvnieka ķermeni un apkārtējo vidi). Vēl viena priekšrocība ir iespēja veikt injekciju, saiti nenovelkot nost.

Lai noskaidrotu vispiemērotāko saites ražošanas tehnoloǵiju, tika aptaujāti veterinārārsti, tādējādi noskaidrojot saitei nepieciešamās īpaš̄ibas, kā arī teorētiski un eksperimentāli tika salīdzināti dažādi pinuma veidi.

Piedāvātās saites tiek izgatavotas, izmantojot zeķu adīšanas mašīnu. Izejmateriāls - kokvilnas dzija kopā ar elastānu. Tiek izmatots mazirstošs pinums, kas ḷauj saiti nogriezt nepieciešamā garumā, kā arī veikt iegriezumus garenvirzienā (atveres dz̄ivnieku kepām).

Saites tika testētas Latvijas Lauksaimniecības universitātê, Veterinārmedicīnas fakultātē. Tās tiek lietotas Baltijas valstu veterinārklīnikās ar nosaukumu „DoubleAid Bandage”.

Алекандр Окс, Илзе Берникова, Елена Окс, Агрис Илгажс. Трикотажные бандажи для защиты ран животных и технология их изготовления. Раны у животных - это одна из самых распространенных патологий в практике ветеринарной медицины, При этом повязки для ран животных - это, как правило, адаптированные перевязочные материалы, используемые в обычной медицине. Однако, учитывая, что животные изначально не являются «партнерами» врача в процессе заживления их повреждений, использование их в ветеринарии встречает ряд физических и технических трудностей. Кроме того, обычные перевязочные материалы могут вызывать и серьезные психологические проблемы у животных. В частности, такие повязки могут вызывать у них чувство беспокойства, изоляции, особенно при контакте с другими животными.

Поэтому разработка повязок для ран животных является актуальной и достаточно сложной проблемой. Для ее решения предложен новый тип повязки (бандажа) для ран, представляющий собой бесконечную трикотажную эластичную трубку, связанную нераспускающимся переплетением, обеспечивающим необходимый воздухообмен и теплозащиту животного.

Основные достоинства предложенного бандажа - экономичность и простота в использовании ветеринарными врачами, удобство для животных (очень легкий и практически не снижает подвижности), возможность использования для защиты шейного отдела и проведения инъекций прямо через бандаж, то есть без его снятия.

Разработана технология производства предложенного бандажа, для чего проведены сравнительные исследования свойств трикотажных полотен с различными переплетениями и заправочными данными и определены переплетения и заправки наилучшим образом обеспечивающие выполнение требований, предъявляемых к повязкам ран животных.

Предложенные бандажи были апробированы на факультете ветеринарной медицины Латвийского сельскохозяйственного университета и получили положительную оценку. В настоящее время они используются в ветеринарных клиниках стран Балтии под названием DoubleAid ${ }^{T M}$ Bandages 